\title{
Zircon geochronology of intrusive rocks from Cap de Creus, Eastern Pyrenees
}

\author{
ELENA DRUGUET*†, ANTONIO CASTRO $\ddagger$, MARTIM CHICHORRO, \\ M. FRANCISCO PEREIRA \& \& CARLOS FERNÁNDEZ\|
}

* Departament de Geologia, Universitat Autònoma de Barcelona, 08193 Bellaterra, Barcelona, Spain ‡UA Petrología Experimental, CSIC-Universidad de Huelva, Facultad de Ciencias Experimentales, Campus de El Carmen, 21071 Huelva, Spain

§GEOBIOTEC, FCT, Universidade Nova de Lisboa, Quinta da Torre, 2829-516 Caparica, Portugal

IDepartamento Geociências, ECT, Universidade de Évora, IDL Apt.94, 7001-554 Évora, Portugal ||Departamento de Geodinámica y Paleontología, Facultad de Ciencias Experimentales, Universidad de Huelva, Campus de El Carmen, 21071 Huelva, Spain

(Received 6 November 2013; accepted 20 January 2014; first published online 11 March 2014)

\begin{abstract}
New petrological and U-Pb zircon geochronological information has been obtained from intrusive plutonic rocks and migmatites from the Cap de Creus massif (Eastern Pyrenees) in order to constrain the timing of the thermal and tectonic evolution of this northeasternmost segment of Iberia during late Palaeozoic time. Zircons from a deformed syntectonic quartz diorite from the northern Cap de Creus Tudela migmatitic complex yield a mean age of $298.8 \pm 3.8 \mathrm{Ma}$. A syntectonic granodiorite from the Roses pluton in the southern area of lowest metamorphic grade of the massif has been dated at $290.8 \pm 2.9 \mathrm{Ma}$. All the analysed zircons from two samples of migmatitic rocks yield inherited ages from the Precambrian metasedimentary protolith (with two main age clusters at c. 730-542 Ma and c. 2.9-2.2 Ga). However, field structural relationships indicate that migmatization occurred synchronously with the emplacement of the quartz dioritic magmas at c. 299 Ma. Thus, the results of this study suggest that subduction-related calc-alkaline magmatic activity in the Cap de Creus was coeval and coupled with $\mathrm{D}_{2}$ dextral transpression involving NNW-SSE crustal shortening during Late Carboniferous - Early Permian time (c. 299-291 Ma). Since these age determinations are within the range of those obtained for undeformed (or slightly deformed) calc-alkaline igneous rocks from NE Iberia, it follows that the Cap de Creus massif would represent a zone of intense localization of $\mathrm{D}_{2}$ transpression and subsequent $\mathrm{D}_{3}$ ductile wrenching that extended into the Lower Permian during a transitional stage between the Variscan and Cimmerian cycles.
\end{abstract}

Keywords: granitoid emplacement, late Variscan transpression, migmatite, SHRIMP ages.

\section{Introduction}

The Cap de Creus massif in the Pyrenees constitutes one of the world's best exposures of rocks displaying ductile deformation structures (Carreras \& Druguet, 2013). The area has been intensively studied and mapped by Carreras and Druguet and is a worldclass example of shear zones affecting a crystalline basement, and also represents a case-study of metamorphic and magmatic activity contemporaneous with transpressional deformation (Druguet \& Hutton, 1998; Druguet, 2001). Field relationships and tectonic analyses clearly suggest that crustal-scale transpression was coeval with magmatic intrusions of varied compositions, and with low-pressure - high-temperature (LP-HT) metamorphism and local partial melting of metasediments. However, neither the petrogenesis of these magmatic rocks, nor the ages of intrusions and associated deformation events have been determined in detail using geochronological data. Our new data may help to constrain the magmatic and tectonic relationships together with the overall tectonic significance of the massif.

†Author for correspondence: elena.druguet@uab.cat
In a regional context, the Cap de Creus massif is considered to be a part of the Variscan basement of NE Iberia (Ábalos et al. 2002) and is the easternmost outcrop of the so-called Axial Zone of the Pyrenees (Fig. 1a). Adjacent to the Axial Zone, the Variscan basement also crops out in the North Pyrenean massifs and southwards from the Axial Zone along the Catalan Coastal Ranges. Based on Variscan lithostratigraphic, metamorphic and tectonic features, a zonation has been defined from internal deep-seated rocks, corresponding to the eastern Pyrenean Axial Zone and the North Pyrenean massifs, to more external shallowseated rocks, corresponding to the western Pyrenean Axial Zone and the southern Catalan Coastal Ranges (Carreras \& Capellà, 1994; Druguet, 2001).

Granitoid plutons extensively intrude along and across all these areas (Fig. 1a). However, differences, which are roughly consistent with the abovementioned Variscan zonation, are found among the various granitoid massifs. Thus, most plutons from the Western and Central Pyrenees and from the Catalan Coastal Ranges correspond to epizonal intrusions, characterized by the development of contact metamorphic aureoles and by the lack of ductile solid-state deformations. They have 